PontIFícIA UNIVERSIDADE CATÓLICA dO RIO DE JANEIRO

O potencial do perfil empreendedor no desempenho dos colaboradores de uma empresa de assessoria de serviços contábeis

Stephanie Christine Regalado de Amorim

Trabalho de Conclusão de Curso

Centro de CiênCIAS SOCIAIS - CCS

DePARTAMENTO de AdMINISTRAÇÃo

Graduação em Administração de Empresas 


\section{O Potencial do Perfil Empreendedor no Desempenho dos Colaboradores de uma Empresa de Assessoria de Serviços Contábeis}

Trabalho de Conclusão de Curso, apresentado ao programa de graduação em Administração da PUC-Rio como requisito parcial para a obtenção do titulo de graduação em Administração.

Orientador(a) : Paulo César Teixeira

Rio de Janeiro Junho de 2017. 


\section{Agradecimentos}

Ao meu orientador, Professor Paulo César Teixeira, por te se prontificado a me receber na Puc, sanando todas as minhas dúvidas e me orientando da melhor maneira para realização de um excelente trabalho.

Aos meus pais, John Dalton H. B. de Amorim e Laura Cristina R. de Amorim, por proporcionarem que eu estudasse em uma das melhores e mais conceituada universidade desse país. Além disso, gostaria de agradecê-los por todo o apoio prestado durante esses cinco anos de graduação, pelo incentivo, pelos conselhos e por estenderem sempre a mão para mim, principalmente nos momentos mais difíceis, fazendo com que eu tivesse força e motivação de continuar lutando.

À minha irmã, Gabrielle Christine R. de Amorim, por ser minha melhor amiga em todas as horas e por me enriquecer de conhecimento a cada dia mais com os sua sabedoria, seus conselhos e suas experiências.

Ao meu namorado, Igor Souza Poltroniéri, por ter ficado ao meu lado durante toda essa trajetória acadêmica, por ter me apoiado em todas as minhas decisões, por ter respeitado os meus momentos de estudo e trabalhos, principalmente quando eu tinha que abrir mão do meu final de semana. $E$, além disso, tudo, por ter me transmitido muito conhecimento diariamente e sendo um dos principais responsáveis pelo meu amadurecimento.

Aos meus amigos Felipe Carvalho, Pedro Gabriel Leite, Camila Garcia, Maiara Oliveira, Matheus Garcia e Henrique Helfer por estarem sempre ao meu lado dividindo os diversos momentos que a faculdade nos proporciona diariamente, por estarem sempre ao meu lado nos momentos de alegria e confraternização e por estenderem sempre a mão nos momentos difíceis, fazendo com que eu seja forte para seguir em frente e obter o tão sonhado sucesso, não só na vida acadêmica como na vida pessoal também. 


\title{
Resumo
}

\author{
Amorim, Stephanie Christine Regalado, Paulo Cesar. O potencial de \\ empreendedorismo dos colaboradores de uma empresa prestadora \\ de serviços contábeis. Rio de Janeiro, 2017. Número de páginas $p$. \\ Relatório Final de Integradora IV. - Departamento de Administração. \\ Pontifícia Universidade Católica do Rio de Janeiro.
}

Em decorrência da atual crise que o país vem enfrentando, diversos setores tradicionais da economia estão sendo afetados diretamente gerando, consequentemente, um aumento expressivo na taxa de desemprego. Com isso, o empreendedorismo vem crescendo cada vez mais no mundo inteiro, tornandose cada vez mais importante para a realização das pessoas e para o desenvolvimento da economia.

O objetivo desse estudo é verificar que apesar das atitudes das pessoas diante dos fatos variarem diariamente, é possível observar os comportamentos mais frequentes, adequando um perfil para cada tipo de pessoa de acordo com os seus comportamentos. É importante ressaltar que não existe um perfil padrão para empreendedores, existe um conjunto de características comuns que são frequentes nos empreendedores de sucesso.

"Acreditamos que todas as pessoas possuem, em maior ou menor grau, características empreendedoras, mas que nem sempre sabem como exercê-las ou não as cultivam. Geralmente isso ocorre por falta de cuidado ou atenção. Somos todos empreendedores, mas precisamos exercitar nossas características empreendedoras e aprender técnicas para aplica-las de modo adequado." (Salim, 2010).

Palavras - chave: Perfil empreendedor; empreendedorismo; inovação; 


\section{Abstract}

Amorim, Stephanie Christine Regalado. The Potential of the Entrepreneurial Profile in the Performance of Employees of an Accounting Services Advisory Company. Rio de Janeiro, 2017. p. Course Completion Work - Business Department. Pontifícia Universidade Católica do Rio de Janeiro.

As a result of the current crisis facing the country, several traditional sectors of the economy are being directly affected, resulting in a significant increase in the unemployment rate. With this, entrepreneurship has been growing more and more in the world, becoming increasingly important for the achievement of people and for the development of the economy.

The objective of this study is to verify that although people's attitudes to the facts vary daily, it is possible to observe the most frequent behaviors, adapting a profile for each type of person according to their behaviors. It is important to emphasize that there is no standard profile for entrepreneurs, there is a set of common characteristics that are frequent in successful entrepreneurs.

"We believe that all people have, to a greater or lesser extent, entrepreneurial characteristics, but they do not always know how to exercise them or do not cultivate them. Usually this is due to lack of care or attention. We are all entrepreneurs, but we need to exercise our entrepreneurial characteristics and learn techniques to apply them properly." (Salim, 2010).

Keywords: Entrepreneurial profile; Entrepreneurship; innovation; 


\section{Sumário}

1 O problema 1

1.1. Introdução 1

1.2. Objetivos 3

1.3. Relevância do Estudo 3

1.4. Delimitação do Estudo 5

2 Referencial Teórico 6

2.1. Conceituando empreendedorismo 6

2.2. O empreendedorismo no mundo 7

2.3. O empreendedorismo no Brasil 9

2.4. A educação empreendedora 9

2.5. A causa da mortalidade das empresas e o destino dos proprietários $\begin{array}{ll}\text { após a mortalidade } & 10\end{array}$

2.6. A experiência como um diferencial e/ou como uma vantagem $\begin{array}{ll}\text { competitiva } & 13\end{array}$

$\begin{array}{ll}\text { 2.7. O desemprego e o empreendedorismo } & 14\end{array}$

$\begin{array}{ll}\text { 2.8. Características dos empreendedores de sucesso } & 17\end{array}$

3 Metodologia de Pesquisa 20

3.1. Tipo de Pesquisa 20

3.2. Universo e Amostra 21

3.3. Seleção dos sujeitos $\quad 21$

3.4. Coleta de dados $\quad 21$

3.5. Tratamento dos dados 22

3.6. Limitações do Método 23

4 Análise de Dados $\quad 24$

4.1. A empresa Erro! Indicador não definido.

4.2. Características da amostra pesquisada 24

4.3. Análise dos resultados 24 
5 Conclusão 32

5.1. Sugestões e recomendações para futuras pesquisas 34

6 Referências Bibliográficas $\quad 35$

\section{Lista de Quadros}

Quadro 1 - Principais causas da mortalidade das empresas

Quadro 2 - Principais pontos fortes e pontos fracos dos colaboradores que responderam o questionário (Anexo 1).

30

\section{Lista de Gráficos}

Gráfico 1 - Atividade dos ex-proprietários após encerrar a empresa (apenas para empresas encerradas)

Gráfico 2 - Percentual de Gênero Masculino e Feminino

Gráfico 4 - Porcentagem Média por Grupo das Principais Características Empreendedoras 
Gráfico 5 - Comparação do perfil das atuais empreendedoras com os demais colaboradores da empresa estudada

\section{Lista de Tabelas}

Tabela 01 - Pontuação e Perfil 


\section{0 problema}

\subsection{Introdução}

O desemprego tornou-se um dos problemas mais críticos e mais sérios referentes à população economicamente ativa. Em razão da crise que estamos vivenciando atualmente acompanhada de uma crescente desaceleração do mercado de trabalho e uma crescente escassez de oportunidades, torna-se cada vez mais necessária a busca do trabalhador por novas oportunidades criadas pelo mesmo de forma decisiva.

De acordo com dados levantados pelo Instituto Brasileiro de Geografia e Estatística-IBGE (2017), no período de abril de dois mil e quinze a abril de dois mil e dezesseis, desapareceram, aproximadamente, trezentos e doze mil empregadores no país, levando o desemprego a atingir picos históricos e registrando o pior momento em vinte e cinco anos. Em decorrência desse cenário cada vez mais competitivo e imprevisível, algumas pessoas são tendenciadas a adquirirem seu próprio negócio por motivos são alheios as suas vontades. Temos como exemplo, profissionais que possuíam um emprego formal, em grandes organizações, e tiveram sua carreira interrompida, por demissões.

O Brasil é um país bastante desafiador para startups e empreendedores. A atual situação é de grande instabilidade econômica, porém crises econômicas podem proporcionar boas oportunidades para quem possui o perfil inovador. Nesse período de maior incerteza e maior instabilidade, o que fica mais evidente são os problemas e as empresas, principalmente as startups focadas em tecnologia, identificam as oportunidades através deles, oferecendo e apresentando soluções nas quais, muitas vezes, ajudam a reverter o atual cenário de instabilidades no país. Uma vantagem de empreender nesse cenário é que, além de se contribuir para a geração de empregos, o empreendedorismo estimula o espirito criativo da população, motivando as pessoas a acreditarem em novas soluções, e se superarem profissionalmente.

"Um empreendedor é uma pessoa que imagina, desenvolve e realiza visões" (Fillion, 1999, pág. 19.). 
As pessoas que possuem um perfil empreendedor são realizadoras de novas ideias através da complementação entre criatividade e imaginação. Em geral, o empreendedor é motivado pela auto realização e pela vontade de adquirir responsabilidades e ser independente. Imaginação, determinação, habilidade de organizar, liderar pessoas e conhecer tecnicamente etapas e processos são as principais características para o alcance do sucesso no empreendedorismo.

"Não há um momento mais adequado para tomar a decisão de largar o emprego e assumir o risco de tocar um novo negócio", afirma o professor Bonomo (2014). Cada caso deverá ser avaliado individualmente, porém um sinal fortemente positivo para esse momento é quando se pode observar que a gestão do empreendimento novo começa a consumir grande parte do tempo diariamente que começa a influenciar na produtividade do trabalho fixo.

Outro momento que transmite um sinal para essa transição é quando o empreendimento próprio apresenta sinais de evolução. "O empreendedor pode começar a receber pedidos, notar um aumento no interesse das pessoas pelo produto ou serviço ou começar a faturar", exemplifica Bonomo (2014). Algumas outras alternativas de observação para a avaliação de que o negócio está crescendo e caminhando para o caminho correto é certificar-se de que a procura e visualização na página do negócio estão crescendo.

Assumindo o contexto e o momento descrito acima, o problema que norteou a presente pesquisa foi: Qual o potencial de empreendedorismo dos colaboradores de uma empresa prestadora de serviços contábeis?

A empresa de assessoria contábil foi fundada em Janeiro de 2014 por três sócias, nas quais duas são contadoras e uma advogada. A grande motivação das mesmas para empreender surgiu através das experiências profissionais anteriores que realizavam de consultoria financeira, na qual havia uma grande demanda por um "bom contador".

Conforme o tempo foi passando e com as experiências que foram adquirindo, elas foram vendo que essa demanda estava de acordo com os seus princípios de serem sempre contadoras e desempenharem o seu trabalho da melhor maneira possível e da forma mais clara e objetiva. A partir disso, identificaram uma grande oportunidade no momento e decidiram criar a empresa de assessoria contábil, tornando o tema contábil e fiscal algo mais simples e de fácil compreensão.

A empresa se responsabiliza em oferecer o serviço a partir de três diferentes formas diferenciadas: terceirização de contabilidade e outros serviços ligados a área, assessoria fiscal, incluindo serviços como declaração de imposto de renda; e folha de pagamento. 


\subsection{Objetivos}

No decorrer dos últimos anos, as organizações vem se readaptando ao atual cenário macroeconômico mundial, repensando sobre suas formas de contratação, de desenvolvimento e conservação dos seus profissionais. A partir desse cenário de grandes mudanças e incertezas, grande parte da população está buscando o empreendedorismo, com melhores e mais estáveis condições de trabalho, com maiores perspectivas de crescimento profissional, proporcionando uma qualidade de vida adversa ao atual momento.

A partir do cenário apresentado acima, esse estudo visa identificar o potencial do perfil empreendedor no desempenho dos colaboradores de uma empresa prestadora de serviços contábeis.

Em torno desse objetivo final, estão presentes alguns objetivos intermediários nos quais buscam:

- Estudar os pressupostos teóricos existentes sobre o empreendedorismo;

- Identificar por meio de uma autoavaliação o perfil dos colaboradores da empresa objeto de estudo.

- Comparar o perfil empreendedor dos colaboradores com o perfil dos empreendedores descritos na literatura.

A partir dos pontos detalhados acima, espera-se alcançar o objetivo final do estudo, fazendo com que, em momentos de crise e incertezas como o do atual cenário, as pessoas consigam identificar, através de suas características pessoais e empreendedoras, uma oportunidade e consigam despertar o desejo e a vontade de desenvolver novas aptidões e habilidades, colocando a frente suas ideias, desejos e oportunidades.

\subsection{Relevância do Estudo}

"Associa o empreendedor ao desenvolvimento econômico, a inovação e ao aproveitamento de oportunidades em negócios" (1934 apud DOLABELLA, 2009, p. 14). O tema desenvolvido busca não só auxiliar no estudo e na pesquisa do empreendedorismo no Brasil como também despertar o espirito empreendedor em cada profissional, fazendo com que, através das características apresentadas e relatadas por profissionais experientes, os mesmos identifiquem grandes oportunidades em meio a uma crise e consequentemente gerem maior 
desenvolvimento econômico para o país. Segundo pesquisa realizada pela Global Entrepreneurship Monitor - GEM (DOLABELLA, 2009, p. 25) concluiu que "a criação de empresas é o instrumento mais eficaz para a geração de empregos, o crescimento econômico, o desenvolvimento social e, consequentemente, para combater a pobreza em uma sociedade.", ou seja, o empreendedor é um dos principais agentes de mudança.

Outro quesito bastante interessante no estudo em questão é a possibilidade de uma autoavaliação e um autoconhecimento. Através do questionário com características pré-estabelecidas, as pessoas tem a oportunidade de se auto avaliarem e conhecerem um pouco mais de si. Muitas vezes, na correria do dia a dia não paramos para pensar no nosso perfil, nos nossos pontos fortes e pontos fracos e, quando não nos conhecemos a fundo podemos estar deixando para trás grandes oportunidades ou até mesmo melhorias pessoais que são importantes para o nosso dia a dia, como por exemplo, como a forma de pensar a agir em determinadas situações no nosso atual ambiente de trabalho.

A partir da análise das autoavaliações do perfil empreendedor dos colaboradores de uma determinada consultoria contábil, também se torna possível conhecer um pouco dos diferentes perfis que estão presentes no mercado de trabalho, com autoavaliações de alguns empreendedores e não empreendedores. Muitas das características pré-estabelecidas no questionário podem fazer parte de um perfil direcionado para as motivações e experiências profissionais, observando-se os pontos fortes e as limitações que podem ocorrer ao empreender ou apenas ao prestar serviço para uma determinada companhia.

Outro ponto bastante interessante do estudo é a possibilidade de integração de empreendedores e não empreendedores em redes de conhecimento, possibilitando que os mesmos estejam atualizados quanto aos diferentes perfis do mercado e até mesmo a possibilidade em obterem parceiros de negócios.

Grande parte das pessoas se queixa por não possuir inovação e criatividade, se queixam por abrirem mão de grande parte do seu tempo para prestar serviço para o seu atual emprego e mesmo assim não ter um devido reconhecimento e, o grande problema é que essa maioria acaba se acomodando nessas situações indesejáveis. No decorrer do estudo é possível conhecer um pouco mais do perfil dos empreendedores e como eles agem nessas situações. Diferentemente da grande maioria, eles estão sempre atrás de novas ideias de negócio e de oportunidades de mercado, mantendo-se sempre atualizados com tudo o que ocorre a sua volta.

O presente estudo possibilita que o leitor tenha uma mente mais aberta, que o mesmo fique mais atento às oportunidades e mais preparado para lidar com as 
possíveis situações corriqueiras. Assim, qualquer fonte de informação pode ser um ponta pé inicial para novas ideias e identificação de oportunidades de mercado. A grande questão é saber identificar e selecionar a melhor oportunidade, sabendo até que ponto elas podem se tornar oportunidades reais de empreendimento.

No decorrer do estudo, existe também a oportunidade de compreender os aspectos e os acontecimentos diários nos quais são responsáveis e fundamentais para as devidas decisões, juntamente com os fatores pessoais, o seja, as razões que contribuíram para a tomada de decisão.

Através de uma pesquisa semiestruturada com um roteiro pré-estabelecido e a partir de uma metodologia qualitativa, se consegue observar de forma mais Adequada o objeto de estudo, ajudando na compreensão do fenômeno de forma indutiva.

\subsection{Delimitação do Estudo}

Foi realizada uma pesquisa em um escritório de uma empresa de assessoria de serviços contábeis localizada no Rio de Janeiro, a qual possui dezoito funcionários com funções e cargos distintos e com idade média de trinta e cinco anos, com perfis empreendedores ou não e com graduação completa. 


\section{Referencial Teórico}

\subsection{Conceituando empreendedorismo}

Para Dornelas (2014), um dos maiores especialistas brasileiros em empreendedorismo e plano de negócios e um dos mais requisitados conferencistas sobre o tema no país, o termo empreendedorismo pode ser definido como o envolvimento de pessoas e processos que, em conjunto, levam à transformação de ideias em oportunidades. A perfeita implementação dessas oportunidades leva à criação de negócios de sucesso. Apesar de existirem diversas definições, talvez a que melhor reflita o espirito empreendedor para o autor Dornelas seja a de Schumpeter (1949): "O empreendedor é aquele que destrói a ordem econômica existente pela introdução de novos produtos e serviços, pela criação de novas formas de organização ou pela exploração de novos recursos e materiais".

Kirzner (1973) propõe uma abordagem diferente. Para ele, o empreendedor é aquele que cria um equilíbrio, encontrando uma posição clara e positiva em um ambiente de caos e turbulência, ou seja, identifica oportunidades na ordem presente. Porém, segundo Dornelas (2014), ambos são enfáticos ao afirmar que o empreendedor é um exímio identificador de oportunidades, individuo curioso e atento às informações, pois sabe que as suas chances melhoram quando o seu conhecimento aumenta.

De acordo com Schumpeter (1949), o empreendedor é mais conhecido como aquele que cria novos negócios, mas pode também inovar dentro de negócios já existentes; ou seja, é possível ser empreendedor dento do empreendedorismo corporativo.

"O empreendedor é alguém que percebe uma oportunidade e cria uma organização para persegui-la" (Bygrave).

Para Aranha (2009):

"O empreendedor é uma pessoa que procura oportunidades. Ele não é um oportunista, que se aproveita de oportunidades. A diferença está no fato de que o empreendedor que tem visão de longo prazo é visionário, sua realização está calcada em missões e objetivos de vida, enquanto os 
oportunistas têm expectativa de curto prazo e justificam seus meios para atingir os fins."

A partir desses conceitos, Dornelas (2014) afirma que o empreendedor do próprio negócio é que aquele que detecta uma oportunidade e cria um negócio para capitalizar sobre ela, assumindo riscos calculados. Em qualquer uma das definições de empreendedorismo citadas anteriormente, encontram-se pelo menos, os seguintes aspectos referentes ao empreendedor, segundo o autor: Tem iniciativa para criar um novo negócio e paixão pelo o que faz; utiliza os recursos disponíveis de forma criativa, transformando o ambiente social e econômico no qual vive; aceitar e assumir os riscos calculados e a possibilidade de fracassar.

Ainda segundo o autor Dornelas (2014), o processo empreendedor envolve todas as funções, atividades e ações associadas à criação de novas empresas. Em primeiro lugar, o empreendedorismo envolve o processo de criação de algo novo de valor. Em segundo, requer a devoção, o comprometimento de tempo e o esforço necessário para fazer a empresa crescer. Em terceiro, que riscos calculados sejam assumidos, e decisões criticas, tomadas; é preciso ousadia e ânimo, apesar de falhas e erros.

O empreendedor revolucionário é aquele que cria novos mercados, ou seja, o individuo que cria algo único, como foi o caso de Bill Gates, criador da Microsoft, que revolucionou o mundo com o sistema operacional Windows. No entanto, a maioria dos empreendedores cria negócios em mercados já existentes, não deixando de ser bemsucedidos por isso (Dornelas, 2014).

\subsection{0 empreendedorismo no mundo}

O empreendedorismo vem crescendo no mundo inteiro e, mais que isso, cada vez mais é tratado como uma questão fundamental para a realização das pessoas (visão dos humanistas) e para o desenvolvimento econômico (visão dos economistas). Dentro dessa ótica é que o empreendedorismo vem obtendo maior apoio de governos, universidades e da sociedade em geral (Salim, 2010).

Segundo Dornelas (2014), o mundo tem passado por várias transformações em curtos períodos, principalmente no século $X X$, quando foi criada a maioria das invenções que revolucionaram o estilo de vida das pessoas.

O contexto atual é propício para o surgimento de um número cada vez maior de empreendedores. Por esse motivo a capacitação dos candidatos a empreendedor vem sendo prioridade em muitos países, inclusive no Brasil (Dornelas, 2014). 
A partir desse atual contexto, o empreendedorismo também tem sido o centro das politicas públicas na maioria dos países. O crescimento do empreendedorismo no mundo se acelerou na década de 1990 e aumentou em proporção nos anos 2000, o que pode ser observado nas ações desenvolvidas com o tema. Alguns exemplos são: programas de incubação de empresas e parques tecnológicos; desenvolvimento de currículos integrados que estimulem o empreendedorismo em todos os níveis, da educação fundamental à universitária; programas e incentivos governamentais para promover a inovação e transferência de tecnologia; subsídios governamentais para criação e desenvolvimento de novas empresas; criação de agencias de suporte ao empreendedorismo e à criação de negócios; programas de desburocratização e acesso ao crédito para pequenas empresas; desenvolvimento de instrumentos para fortalecer o conhecimento da propriedade intelectual, entre outros (Dornelas, 2014).

Ainda segundo Dornelas (2014), em todo o mundo, o interesse pelo empreendedorismo se estende além das ações dos governos nacionais, atraindo também a atenção de muitas organizações e entidades multinacionais, como ocorre na Europa, nos Estados Unidos e na Ásia. Há uma convicção de que o poder econômico dos países depende de seus futuros empresários e da competitividade de seus empreendimentos.

A explicação para focalização de um número cada vez maior de países no empreendedorismo pode ser obtida ao se analisar o que ocorre nos Estados Unidos. Trata-se do maior exemplo de compromisso nacional com o empreendedorismo e o progresso econômico. Mesmo com a recente crise econômica mundial, da qual os Estados Unidos têm sido protagonistas, o que tem acarretado corte orçamentário em várias áreas, no que se refere ao empreendedorismo, ocorre ao contrário, haja visto a crença de que o empreendedorismo é e continuará sendo o grande propulsor do desenvolvimento econômico (Dornelas, 2014).

Todos os fatores levaram um grupo de pesquisadores a organizar, em 1997, o projeto Global Entrepreneurship Monitor (GEM), iniciativa conjunta do Babson College, nos Estados Unidos e na London Business School, na Inglaterra, com o objetivo de medir a atividade empreendedora dos países e observar seu relacionamento com o crescimento econômico. (Dornelas, 2014, p. 13).

Mais importante do que o resultado obtido pela medição do grau de Empreendedorismo de um país é o diagnóstico feito em cada pesquisa anual, que aponta os fatores que têm ajudado a incentivar $o$ desenvolvimento do Empreendedorismo no país e as barreiras identificadas como obstáculos à sua difusão (Salim, 2010). 


\subsection{0 empreendedorismo no Brasil}

"O Brasil não é para participantes", já dizia Antonio Carlos Jobim referindo-se às dificuldades decorrentes do modo como o sucesso de uma pessoa é encarado pelas demais em nosso país (Salim, 2010).

O movimento do empreendedorismo no Brasil começou a tomar forma na década de 1990, quando entidades como o SEBRAE - Serviço Brasileiro de Apoio às Micro e Pequenas Empresas - e a Sociedade Brasileira para exportação de Software (Softex) foram criadas. Antes disso, praticamente não se falava em empreendedorismo e criação de pequenas empresas. Os ambientes político e econômico do país não eram propícios, e o empreendedor praticamente não encontrava informações para auxiliá-lo na jornada empreendedora (Dornelas, 2014).

Segundo Salim (2010), no Brasil, o Estado exerce um forte papel na economia, representando mais da metade do PIB (Produto Interno Bruto) do país, tendo reduzido essa participação após o processo da privatização de diversas empresas estatais.

\subsection{A educação empreendedora}

Não há dúvidas quanto à importância da educação para o ser humano. Seria possível ensinar a ser empreendedor? O relatório da conferência de Oslo (Comissão Europeia, 2006) retrata que ainda existe uma falta de cultura e avaliação de impacto das iniciativas de educação empreendedora. O grande desafio reside em como estimular, desenvolver e fomentar o pensamento criativo e inovador, dado que não se equaciona facilmente como ensiná-lo/ inseri-lo no contexto da educação/ treinamento. (Lopes, 2010).

Os aspectos a seguir demonstram quão amplos e distintos podem ser os objetivos da educação empreendedora (Rabbior, 1990 em Guimarães, 2002):

- Conscientizar a respeito do empreendedorismo e da carreira empreendedora, lançando sementes para o futuro.

- Influenciar/ desenvolver atitudes, habilidades e comportamentos empreendedores.

- Desenvolver qualidades pessoais relacionadas às competências necessárias para o mundo moderno: criatividades, assumir riscos e assumir responsabilidades.

- Incentivar e desenvolver empreendedores. 
- Estimular a criação de negócios/ novas iniciativas. Apoiar o desenvolvimento dessas.

- Gerar empregos.

- Desenvolver conhecimentos, técnicas e habilidades focados no mundo dos negócios e necessários para a criação de uma empresa.

- Auxiliar empreendedores e empresas, através do conhecimento e ferramentas, a melhorar sua competitividade.

De modo geral, pode-se perceber através da relação descrita acima que essa educação pode enfocar a formação do individuo ou focar naquele que se interessa por uma oportunidade e que estaria numa fase anterior á criação de um negócio; pode, ainda, voltar-se para os que já estariam na fase de criação de um empreendimento e, até mesmo, para aqueles que estão em fases posteriores à criação e que estão preocupados com as estratégias para permanecer ativo ou expandir o negócio (Lopes, 2010).

Filion (1999) também destaca que a educação empreendedora é diferente do processo de ensino tradicional por se calcar mais na atividade do próprio aluno, numa forma mais experimental, mais prática e contextualizada no mundo real e que prepara o indivíduo para lidar com as incertezas, falta de recursos e a indiferenciação típica do inicio de uma organização/ iniciativa. E que incentiva a imaginação e análise.

Dolabela (2003) descreve o ciclo de aprendizagem empreendedora: primeiro, o individuo desenvolve um sonho - um projeto futuro que deseje implementar ou algo que deseje alcançar ou se tornar. Depois deve procurar formas de concretizar esse sonho, e para isso deve identificar e aprender o que seja necessário para que possa realiza-lo. O objetivo final deve ser formar indivíduos preparados para alcançar sucesso, independentemente de virem a iniciar novas empresas.

Segundo a autora Lopes (2010), ainda que recente, a educação empreendedora mostrou que não é um modismo. O desafio pedagógico é envolver os estudantes no processo, sentimental e emocionalmente, e criar um ambiente aberto e de confiança para estimular o risco. Faz-se necessário ampliar a base de professores de empreendedorismo, assim, o corpo docente deve ser incentivado, e os sucessos e as inovações devem ser destacadas através de premiações.

\subsection{A causa da mortalidade das empresas e o destino dos proprietários após a mortalidade}

“Em um ambiente competitivo no qual vivemos diariamente, é fundamental ter consciência daquilo que influencia diretamente as nossas 
ações, procurando deixar, em segundo plano, outros fatores de menor relevância. Isso ocorre fundamentalmente em virtude do excesso de informações de que dispomos e da velocidade e constância com que o ambiente de mercado muda. Portanto, o entendimento da complexidade que envolve as ações de um empreendedor, seja na empresa, seja na carreira, é fundamental." (Lenzi, 2008, p. 17)

Há aproximadamente 10 anos, o SEBRAE-SP vem monitorando sistematicamente a taxa de mortalidade das empresas recém-construídas, período em que é maior o risco de fechamento, e os fatores que têm sido determinantes para sua sobrevivência. Durante esse período verificou-se que, em geral, as causas desse fenômeno sofrem pouca variação. A cada novo estudo, constatou-se também que não é possível atribuir a um único fator a causa da mortalidade das empresas (SEBRAESP, 2008).

No quadro 1 do livro 10 Anos de Monitoramento da Sobrevivência e Mortalidade das Empresas/ SEBRAE-SP (2008, p. 60), estão relacionados os principais fatores nos quais influenciam para o encerramento prematuro dos negócios, acompanhado também pela evolução recente dos mesmos e as principais recomendações.

Esse ciclo de dificuldades é alimentado pelo próprio empreendedor de antiga geração que se deixa levar por situações negativas, ou seja, em vez de interferir no seu destino, ele se deixa levar pelas ondas turbulentas. (Lenzi, 2008).

O empreendedor de nova geração deve agir mesmo diante dessas dificuldades, buscando alternativas individuais e conjuntas para mudar esse quadro. Se não houver uma ação dos próprios empreendedores, dificilmente alguém os ajudará olhando a situação apenas de fora. (Lenzi, 2008). 


\section{Quadro 1 - Principais causas da mortalidade das empresas}

\begin{tabular}{|c|c|c|}
\hline $\begin{array}{l}\text { Fatores contribuintes } \\
\text { da mortalidade de } \\
\text { empresas }\end{array}$ & $\begin{array}{l}\text { Evoluçüo } \\
\text { recente }\end{array}$ & $\begin{array}{c}\text { PPINCIPAIS } \\
\text { RECOMENDAÇOES }\end{array}$ \\
\hline $\begin{array}{l}\text { 1- Ruserilid du } \\
\text { comportamento } \\
\text { empreendedor }\end{array}$ & Positiva & $\begin{array}{l}\text { As caracteristicas empreendedoras } \\
\text { (conhccimcntos, habilidadcj c atitu } \\
\text { des) apresentaram ligeira melhora, } \\
\text { mas precisam ser aprimoradas. } \\
\text { Participaçäo em cursos sobre empre- } \\
\text { endedorismo podem ajudar. }\end{array}$ \\
\hline $\begin{array}{l}\text { 2-Ausência do } \\
\text { planejamento previo }\end{array}$ & Positiva & $\begin{array}{l}\text { O planejamento antes da abertu- } \\
\text { ra pode ser melhorado (ainda } \\
\text { deficiente para multos empreende- } \\
\text { dores). Participaçdo em cursos de } \\
\text { planejamento e um preparo mals } \\
\text { apurado antes da abertura (malor } \\
\text { tempo e maior profundidade no } \\
\text { planejamento) podem ajudar. }\end{array}$ \\
\hline $\begin{array}{l}\text { 3-Deficiências na } \\
\text { gestao empresarlal }\end{array}$ & Năo Melhorou & $\begin{array}{l}\text { As deficiências na gestão do negócio, } \\
\text { após a abertura, continuam presen- } \\
\text { tes e precisam ser solucionadas (ex.: } \\
\text { aperfeiçoamento de produtos, fluxo } \\
\text { de caixa, propaganda e divulgação, } \\
\text { gestão de custos e busca de apoio/ } \\
\text { auxilio). Cursos de gestăo empre- } \\
\text { sarial, participaçảo em palestras e } \\
\text { açōes conjuntas com empresas do } \\
\text { mesmo ramo podem ajudar. }\end{array}$ \\
\hline $\begin{array}{l}\text { 4- Insuficiéncia de } \\
\text { politicas de apolo }\end{array}$ & Positiva & $\begin{array}{l}\text { As politicas de apoio têm evoluido } \\
\text { positivamente, mas podem ser } \\
\text { aperfeiçoadas (p. ex., reduzindo o } \\
\text { pesu dus inupustus e Ja Luruciacia, } \\
\text { ampliando o crédito para a produçajo } \\
\text { e maior acesso às compras govema- } \\
\text { mentais). }\end{array}$ \\
\hline $\begin{array}{l}\text { 5-Problemas de } \\
\text { conjuntura econômica }\end{array}$ & Positiva & $\begin{array}{l}\text { A conjuntura melhorou, mas é preci- } \\
\text { so ter continuidade no crescimento } \\
\text { da economia, na estabilidade de } \\
\text { preços e na recuperaçāo da renda } \\
\text { dos trabalthadores. }\end{array}$ \\
\hline 6- Problemas "pessoais' & Não Melhorou & $\begin{array}{l}\text { As empresas continuam sendo muito } \\
\text { afetadas por problemas pessoais de } \\
\text { seus sócios proprietários, tais como: } \\
\text { problemas de saúde, problemas } \\
\text { particulares, problemas com sócios, } \\
\text { sucessão empresarial e vitimas de } \\
\text { criminalidade. Maior profissionalis- } \\
\text { mo, melhor divisáo de tarefas, maior } \\
\text { delegação de responsabilidades e } \\
\text { separaça da vida pessoal dos negó- } \\
\text { cios podem reduzir esses impactos. }\end{array}$ \\
\hline
\end{tabular}

Fonte: Observatório das MPEs do SEBRAE-SP (2008).

A partir da análise acima da evolução recente dos fatores contribuintes para a mortalidade das empresas, pode-se observar que os mesmos apresentaram uma evolução positiva no período avaliado. Com isso, a conjuntura econômica e as politicas de apoio aos pequenos negócios evoluíram positivamente, favorecendo o ambiente desses negócios. Já no nível dos indivíduos, identificou-se uma proporção maior de empreendedores que buscam por cursos e maior intensidade do levantamento de informações antes da abertura. Os fatores da gestão empresarial e 
dos problemas pessoais não apresentaram evolução positiva durante o período analisado, e demandam maior atenção no sentido de evitar que prejudiquem a sobrevivência dos pequenos negócios (SEBRAE-SP, 2008).

O encerramento de um negócio não representa necessariamente o abandono do espirito empreendedor. No gráfico 1 a seguir pode-se observar quais foram os destinos dos ex-proprietários após encerrar a empresa. (SEBRAE-SP, 2008, p.64). Um fator bastante curioso na análise é que a soma dos empresários, que representa $24 \%$, e a soma dos que viraram autônomos, representada em $21 \%$, totalizam $45 \%$, nas quais essas ocupações podem ser consideradas como empreendedoras.

\section{Gráfico 1 - Atividade dos ex-proprietários após encerrar a empresa (apenas para empresas encerradas)}

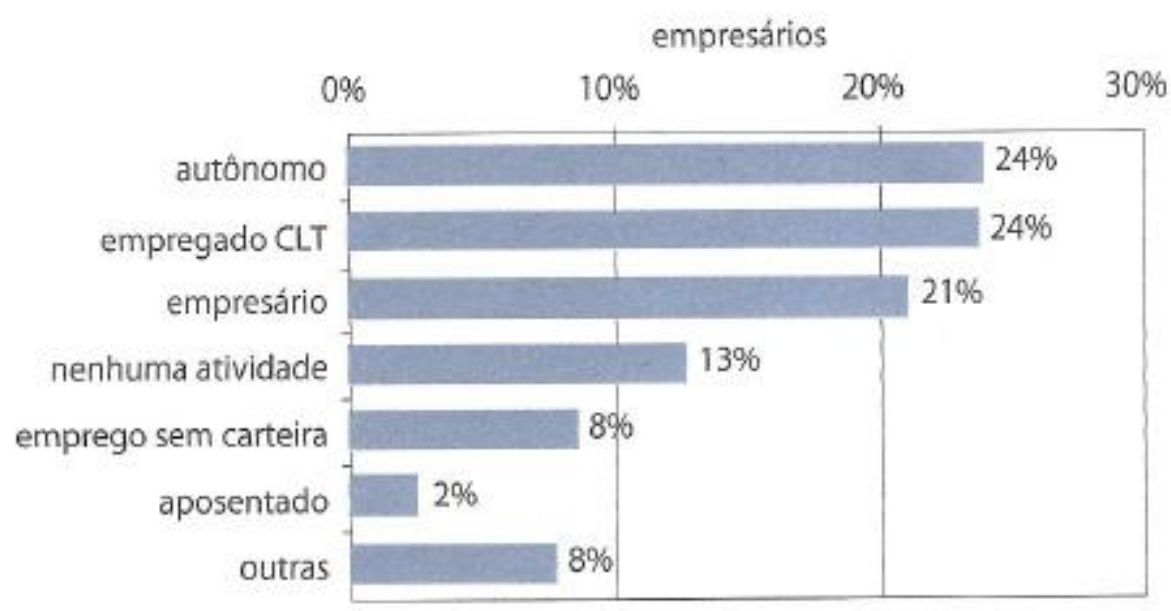

Fonte: Observatório das MPEs do SEMBRAE-SP

\subsection{A experiência como um diferencial e/ou como uma vantagem competitiva}

Dornelas (2014) afirma que as vantagens competitivas estão necessariamente ligadas a diferenciais que proporcionam um ganho para o consumidor. Segundo ele, isso pode ocorrer por meio de um custo menor de produção, de estruturas enxutas e de criatividade no processo de obtenção do produto, que, por fim, levam a um produto ou serviço de menor custo e, consequentemente, de menor preço final. Nesse caso, o diferencial é o menor custo.

As barreiras de entrada para novos competidores e até mesmo para antigos competidores consistem em uma grande vantagem competitiva na qual a empresa deve saber aproveitar. Alguns exemplos de barreiras de entrada são: regulamentação 
governamental, concessão, um contrato de longo prazo com um grande comprador, acordos com fornecedores e distribuidores, etc. (Dornelas, 2014).

Especialistas no tema, como Dornelas (2014), aconselha as pessoas que tem de vontade de empreender a procurar negócios em áreas nas quais possua algum conhecimento ou possua alguma experiência, tenha trabalhado ou tenha sócios que já trabalharam. Não é aconselhável que, em momentos como os que estamos vivenciando ultimamente, arrisque tudo em negócios cuja dinâmica do mercado e cuja forma operacional de gerir a empresa você desconheça, só porque simpatiza com o assunto ou porque é uma área na qual você poderá fazer muito dinheiro. Até porque, conforme vimos anteriormente, em primeiro lugar vem à paixão pelo negócio; ganhar dinheiro é apenas uma consequência.

Continuando a análise de Dornelas (2014), outro fator que deve ser considerado é a formação de equipe. Se os membros da equipe tiverem formação eclética, multidisciplinar, será um grande diferencial competitivo, pois, nesse caso, ela será composta por perfis com habilidades complementares.

O que deve ficar claro é que o empreendedor deve pensar muito bem em que vida quer levar, projetar mentalmente as dificuldades pelas quais passará e se questionar se está disposto a encarar o desafio. Deve ainda planejar bem os passos a serem dados e estar capacitado para atuar na área pretendida, fazendo cursos, participando de eventos, treinamentos, feiras, etc, com a certeza de que conhece o solo no qual está pisando (Dornelas, 2014).

\subsection{O desemprego e o empreendedorismo}

Em alturas de crise como a que vivemos atualmente e que se faz acompanhar de uma forte retração do mercado de trabalho e de níveis de desemprego elevados, a criação de emprego pelos próprios trabalhadores torna-se uma questão decisiva (Hespanha, 2013).

A vida do empreendedorismo tem assumido crescente importância no quadro das politicas de incentivo ao emprego. De facto, a criação de novas empresas tem um grande peso na economia em termos de criação de emprego e de modernização das mesmas e, esse facto tem vindo a assumir crescente importância no seio das politicas públicas nacionais e comunitárias do crescimento econômico (Almeida, 2013).

Segundo Burns (2001), um empreendedor é definido pelas suas ações, não pelo tamanho do seu empreendimento. "Small is beautiful", afirma Schumacher (1973), um gestor de uma empresa de larga escala pode ser (ou não) um empreendedor. 
Acrescer que, ligar características pessoais de um individuo ao sucesso do seu empreendimento é uma questão que exige precaução (Burns, 2001).

A compreensão do significado e dos acontecimentos que a perda de emprego evolve constitui-se como elementos fundamentais para a inteleção dos mecanismos complexos que estão no âmago de processos volitivos de criação do próprio emprego. É, assim, o propósito de compreender, enquanto questão de investigação, os fatores pessoais e contextuais (processos e condições), isto é, as razões que contribuíram para a tomada de decisão de sair de uma situação de desemprego, criando o próprio emprego, e como a interação entre estes fatores pode conjugar-se em contextos de empreendedorismo (Almeida, 2013).

Deste modo, torna-se imperioso para a compreensão de fenômenos potenciadores destas transições, procurar na diversidade experiências individuais da vivencia do desemprego involuntário, elos de ligação, fatores e elementos de aproximação ou diferenciação que possam iluminar os processos subjacentes à transição do desemprego involuntário para a criação do próprio emprego (Almeida, 2013).

Segundo Gonçalves e Coimbra (2007), mesmo face a crescente escassez e precarização do emprego e de argumentos que questionam a importância do trabalho, este continua a assumir um papel central na vida das pessoas e continua a ser uma das maiores fontes de autonomia e cidadania. Segundo Rifkin (1996), citado por Gonçalves Coimbra (2007, pp. 411-412):

"A ideia do cidadão "produtivo" está tão energizada nas sociedades que uma pessoa a quem seja recusado o acesso ao emprego corre o risco de perder toda a sua autoestima e o seu sentido de cidadania".

Assim, estar empregado é ser "destituído de valor" e de poder. Como afirma Castel (1998, p.578), o trabalho continua a ser uma "referência não só economicamente, mas também psicologicamente, culturalmente e simbolicamente".

Experienciar uma situação de desemprego, quando involuntária, pode ser fonte de grande stress e trazer consequências psicossociais potencialmente graves. (Almeida, 2013). Esse fenômeno pode ser ainda mais complexo e multiforme do que se podia pensar. (Paugam, 2003). Para além de suas visíveis consequências a nível pessoal, familiar e comunitário (e para as redes sociais que os desempregados se inserem), do ponto de vista econômico, reflete um subaproveitamento do potencial humano, afastando uma grande parte dos indivíduos dos processos produtivos, com consequências diretas na diminuição do poder de compra (Hespanha et al, 2007). 
Assim, segundo Jaccard (1974), o trabalho corresponde a uma necessidade espontânea do ser humano, fruto da satisfação e realização, onde os indivíduos encontram a sua expressão mais natural, desde que certas condições de ordem psicológica, moral e social estejam asseguradas.

A este propósito, Fouad e Bynner (2008) fazem a distinção entre dois tipos de transições no trabalho, nomeadamente a transição voluntária, orientada pela iniciativa pessoal, e a transição involuntária, moldada por constrangimentos pessoais e ambientais. Assim, as transições voluntárias incluem experiências como mudar da escola para o trabalho, de trabalho ou de carreira. Por outro lado, as transições involuntárias incluem os despedimentos, as reformas forçadas, o reentrar no mercado de trabalho devido a mudanças políticas, as mudanças nas circunstancias pessoas e as mudanças no ambiente de trabalho. Estes processos de transição são frequentemente acompanhados por um número de obstáculos em relação a oportunidades, que incluem: barreiras individuais (não possuir informação suficiente para tomar uma boa decisão, não ter tempo para preparar a transição, ou não ter o apoio social, emocional ou financeiro para o ajustamento à transição); barreiras ambientais (racismo, sexismo, o preconceito em relação à idade, uma economia lenta , níveis elevados de desemprego, e o "timing" imprevisível das oportunidades); e barreiras institucionais (as políticas que afetam as oportunidades educacionais, ou os programas de apoio do governo para aqueles que não estão a trabalhar - subsidio de desemprego e benefícios de segurança social).

Portela et al. (2008) denomina igualmente a atenção para a voluntariedade de muitos despedimentos. Segundo ele, são muitos os casos de pessoas numa posição mais vulnerável face ao mercado de trabalho (mulheres, minorias étnicas, indivíduos com baixas qualificações, etc.) em que o despedimento se deveu a fatores externos, levando a certo "desencanto" com as experiências do trabalho assalariado e criando a expectativa de que o auto emprego se afigure como uma saída de situações de instabilidade e vulnerabilidade laboral.

Alguns autores como, Oxenfeldt (1943), defendem que os indivíduos escolhem entre o desemprego, o auto emprego e o emprego, tendo em conta os "custos" relativos dessas atividades. Nesse sentido, os indivíduos desempregados que enfrentam perspectivas de emprego de salário baixo escolhem o auto emprego como a melhor opção de entre as várias alternativas. Á luz desta teoria, os indivíduos decidem encetar uma atividade empreendedora, pelo que, nesta perspectiva, 0 desemprego atua como catalisador dessa atividade. Esta teoria insere-se, como define o Global Entrepreneurship Monitor, no chamado "empreendedorismo por necessidade". 
Do outro lado, estão os autores que defendem que altos níveis de empreendedorismo reduzem o desemprego. O fenômeno conhecido por "Schumpeter effect" preconiza que o aumento dos níveis de empreendedorismo leva a maiores níveis de emprego e de crescimento econômico. De acordo com tal perspectiva, através da criação de novas empresas e da subsequente contratação de pessoas, incorre-se um processo de redução de desemprego e de aumento de empregabilidade. Por seu turno, a elevadas taxas de desemprego está associado a um baixo nível de atividade empreendedora, ou seja, se a propensão para criar empresas é baixa, isso irá refletir-se em altas taxas de desemprego. (Oladele, Akeke \& Oladunjoye, 2011).

Alguns autores revelam a influência do desemprego como fator "push" e "pull" nos diferentes níveis de análise: individual, local e nacional (cf., Caliendo \& Kritikos, 2010).

As motivações de "push" dizem respeito a circunstâncias em que o individuo, perante perspectivas negativas face á sua inserção no mercado de trabalho (desemprego ou emprego precário), se sente forçado a criar um negócio. As motivações "pull" enquadram-se em situações em que indivíduos são, primeiramente, atraídos pela perspectiva de criar um negócio (Storey, 1991). Segundo Ritsila e Tervo (2002) esta hipótese sugere que a formação de novos negócios ocorre quando a procura é alta e quando os indivíduos têm acesso a crédito ou a poupanças pessoais. Neste sentido, uma decisão positiva de iniciar um negócio é mais provável quando o desemprego é baixo e o indivíduo está empregado e tem acesso ao capital necessário para iniciar o negócio.

\subsection{Características dos empreendedores de sucesso}

Dornelas (2014), através de suas experiências e seu longo tempo de estudo sobre o assunto abordado, afirma que o empreendedor de sucesso possui características extras, além dos atributos do administrador; e alguns atributos pessoais que, somados a características sociológicas e ambientais, permitem o nascimento de uma nova empresa. De uma ideia, surge uma inovação, e desta, uma empresa. A seguir estão listadas as características comuns aos empreendedores em potencial citadas e avaliadas pelo especialista.

Comprometimento e determinação

- É proativo na tomada de decisão.

- É tenaz e obstinado.

- Tem disciplina e dedicação. 
- É persistente ao resolver problemas.

- É disposto ao sacrifício para atingir metas.

- É capaz de imersão total nas atividades que desenvolve.

Obsessão pelas oportunidades

- Procura ter conhecimento profundo das necessidades dos clientes.

- É dirigido pelo mercado (Market driven).

- É obcecado por criar valor e satisfazer aos clientes.

Tolerância ao risco, ambiguidade e incertezas

- Corre riscos calculados (analisa tudo antes de agir).

- Procura minimizar os riscos.

- Tolera as incertezas e falta de estrutura.

- Tolera o estresse e conflitos.

- É hábil em resolver problemas e integrar soluções.

Criatividade, autoconfiança e habilidade de adaptação

- Não é convencional, tem cabeça aberta, pensa.

- Não se conforma com o status quo.

- É hábil em se adaptar a novas situações.

- Não tem medo de falhar.

- É hábil em definir conceitos e detalhar ideias.

Motivação e superação

- É orientado para metas e resultados.

- É dirigido pela necessidade de crescer e atingir melhores resultados.

- Não se preocupa com status e poder.

- Tem autoconfiança.

- É ciente de suas fraquezas e forças.

- Tem senso de humor e procura estar animado.

Liderança

- Tem iniciativa.

- Tem poder de autocontrole.

- Transmite integridade e confiabilidade.

- É paciente e sabe ouvir.

- Sabe construir times e trabalhar em equipe.

Salim (2010 p. 28), afirma: 
"Acreditamos que todas as pessoas possuem, em maior ou menor grau, características empreendedoras, mas que nem sempre sabem como exercêlas ou não as cultivam. Geralmente, isso ocorre por falta de cuidado ou atenção. Somos todos empreendedores, mas precisamos exercitar nossas características empreendedoras e aprender as técnicas para aplica-las de modo adequado". 


\section{Metodologia de Pesquisa}

\subsection{Tipo de Pesquisa}

De acordo com o estudo feito por Vergara (2007), pode-se deparar com diversos tipos de pesquisa, conforme os critérios utilizados pelos autores. Porém, a mesma propõem dois critérios básicos: pesquisa quanto aos fins e a pesquisa quanto aos meios.

Quanto aos fins, a pesquisa pode ser: exploratória, descritiva, explicativa, metodológica, aplicada e intervencionista. (Vergara, 2007). Para o estudo em questão, quanto aos fins, foram utilizadas as pesquisas descritiva e explicativa.

Segundo Vergara (2007, p.45), a pesquisa descritiva expõe características de determinada população ou de determinado fenômeno. Pode também estabelecer correlações entre variáveis e definir sua natureza. Não tem compromisso de explicar os fenômenos que descreve, embora sirva de base para tal explicação.

A partir da afirmação acima, o presente artigo utilizou a pesquisa descritiva visando descobrir, através de uma auto avaliação e através de características préestabelecidas por Dornelas (2014) do perfil empreendedor, se os colaboradores de uma determinada empresa de prestação de serviços contábeis possuíam o perfil empreendedor, podendo utilizá-las para se diferenciar no mercado de trabalho, ou se apesar de possuir algumas características, haveria uma necessidade de aperfeiçoamento de alguns pontos fracos e equilíbrio entre esses pontos com os pontos fortes.

De acordo com Vergara (2007, p.45), a investigação explicativa tem como principal objetivo tornar algo inteligível justificar-lhe os motivos. Visa, portanto, esclarecer quais fatores contribuem de alguma forma, para a ocorrência de determinado fenômeno.

A partir disso, a pesquisa aplicada é explicativa, pois após de ter sido respondida pelos colaboradores de uma empresa de prestação de serviços contábeis, houve uma comparação do perfil empreendedor dos colaboradores com o perfil dos empreendedores descritos na literatura, avaliando como essas características podem afetar de forma positiva na organização estudada. 
A pesquisa quanto aos meios de investigação pode ser divida em: pesquisa de campo, pesquisa de laboratório, telematizada, documental, bibliográfica, experimental, ex post facto, participante, pesquisa-ação e estudo de caso. (Vergara, 2007, p.45).

Quanto aos meios, a pesquisa aplicada é de campo e bibliográfica. De campo porque foi enviado eletronicamente um questionário estruturado com o objetivo de identificar, através de uma autoavaliação, o perfil dos colaboradores de uma determinada empresa de prestação de serviços contábeis. A pesquisa também é considerada bibliográfica, pois foi realizado um estudo com base em materiais publicados em livros para auxiliar no desenvolvimento dos objetivos. E, também representa um estudo de caso, pois se tem uma questão a ser estudada, ou seja, o perfil dos atuais colaboradores da empresa em questão e reproduz questionamentos, incertezas e as possibilidades de um atual contexto empresarial que influencia nas decisões desses colaboradores.

\subsection{Universo e Amostra}

Foi aplicada uma pesquisa de auto avaliação em uma empresa de assessoria de serviços contábeis, localizada no Centro do Rio de Janeiro, na qual fazem parte dezoito funcionários, com idade média de trinta e cinco anos e com profissões que variam entre analista de departamento pessoal, economista, administrador e contador.

A pesquisa não possui uma amostra, pois cem por cento dos colaboradores da empresa responderam a pesquisa aplicada.

\subsection{Seleção dos sujeitos}

Os sujeitos da pesquisa são colaboradores com idade média de 35 anos, com no mínimo uma graduação completa, residentes do Estado do Rio de Janeiro e que estão trabalhando atualmente na empresa prestadora de serviços contábeis em questão. Os respondentes da pesquisa aplicada foram anônimos.

\subsection{Coleta de dados}

Foi realizada uma pesquisa bibliográfica em livros sobre o estudo do Empreendedorismo, para a organização da base teórica do assunto.

A coleta de dados foi realizada através de uma pesquisa de campo, com um roteiro semiestruturado com os colaboradores de uma empresa prestadora de serviços contábeis, de acordo com a especificação feita no item do universo e amostra. 
O questionário (Anexo 1) foi aplicado por escala com a finalidade de quantificar as respostas. O mesmo é fechado, com uma autoavaliação de aproximadamente 30 características, nas quais os colaboradores devem atribuir um número de acordo com a escala com opções pré-estabelecidas. O questionário (Anexo 1) foi estruturado através da opção de extrair formulários pelo Google Drive, sendo aplicado e respondido via internet.

\subsection{Tratamento dos dados}

Segundo Vergara (2007), os dados podem ser tratados de forma quantitativa, isto é, utilizando-se procedimentos estatísticos, como o teste de hipóteses e de forma qualitativa, como por exemplo, codificando-os, apresentando-os de forma mais estruturada e analisando-os.

O questionário (Anexo 1) aplicado foi desenvolvido por Dornelas (2007), no livro "Empreendedorismo: Transformando ideias em negócios", $5^{\text {a }}$ edição, cujo objetivo é avaliar o perfil dos profissionais que já atuam no mercado de trabalho e concluir se os mesmos possuem um perfil empreendedor ou se precisam aperfeiçoar algumas características pessoais.

Os dados foram extraídos da ferramenta de pesquisa do Google Drive, a qual disponibiliza o resultado através de gráficos e estatísticas para que proporcione uma melhor visualização e compreensão do resultado obtido. Posteriormente, os dados foram transferidos para a ferramenta Excel e tratados de forma qualitativa, com uma análise mais detalhada, como por exemplo, a pontuação total obtida por cada participante na pesquisa e a média de pontuação para cada característica autoavaliada, no intuito de obter uma conclusão mais especifica de cada perfil.

Cada participante atribuiu uma nota numa escala de 1 a 5 , sendo 1 insuficiente, 2 fraco, 3 regular, 4 bom e 5 excelente, e o desempenho de cada participante da pesquisa poderia ficar entre uma pontuação inferior a 59 pontos até 150 pontos, sendo: inferior a 59 pontos um perfil de não empreendedor, entre 60 e 89 pontos um perfil não muito empreendedor, entre 90 e 119 um perfil com muitas características empreendedoras e entre 120 e 150 com um provável perfil empreendedor atualmente.

Tabela 01 - Pontuação e Perfil

\begin{tabular}{|c|c|}
\hline Pontuação & Perfil \\
\hline 120 a 150 pontos & Provavelmente já é um empreendedor \\
\hline 90 a 119 pontos & Possui muitas características \\
& empreendedoras \\
\hline
\end{tabular}




\begin{tabular}{|c|c|}
\hline 60 a 89 pontos & Ainda não é muito empreendedor \\
\hline Menos de 59 pontos & Não é empreendedor \\
\hline
\end{tabular}

Fonte: A autora (2017).

\subsection{Limitações do Método}

Todo método tem possibilidades e limitações. É saudável antecipar-se às criticas que o leitor poderá fazer ao trabalho, explicitando quais as limitações que o método escolhido oferece, mas que ainda assim o justificam como o mais adequado ao propósito de investigação. (Vergara, 2007, p. 59).

A principal limitação encontrada na aplicação do questionário é o fato da pessoa atribuir uma nota alta para uma característica que não possui ou vice e versa para poder chegar a um perfil empreendedor desejado.

Outra limitação que pode ser encontrada é referente ao tamanho da amostra. Como a pesquisa foi feita em uma determinada empresa, o número de respondentes ficou muito limitado à quantidade de funcionários. 


\section{Análise de Dados}

\subsection{Características da amostra pesquisada}

A pesquisa foi realizada com 18 colaboradores de uma empresa de assessoria contábil sem nenhum tipo de restrição em relação à idade e sexo. Responderam de forma aleatória todos os colaboradores da empresa, sendo 7 mulheres nas quais representam $38 \%$ dos colaboradores e 11 homens nos quais representam $61 \%$, conforme demonstra o gráfico 2.

\section{Gráfico 2 - Percentual de Gênero Masculino e Feminino}

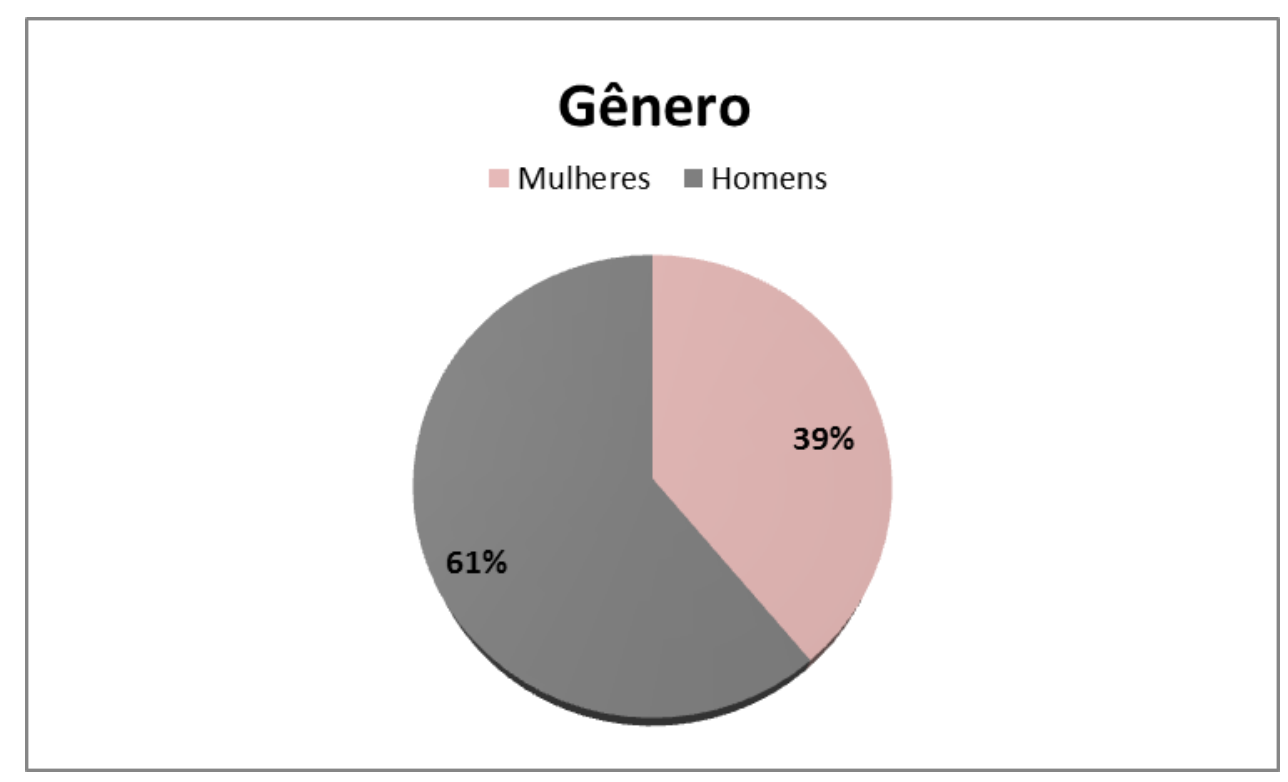

Fonte: A autora (2017)

\subsection{Análise dos resultados}

O questionário aplicado foi desenvolvido por Dornelas (2007) com o objetivo de se analisar o desempenho individual de cada pessoa que respondeu a pesquisa, chegando, a partir de uma determinada pontuação, a diferentes perfis empreendedores, a saber: 
- Perfil 1: 120 a 150 pontos: você provavelmente já é um empreendedor, possui as características comuns aos empreendedores e tem tudo para se diferenciar no mundo dos negócios.

- Perfil 2: 90 a 119 pontos: você possui muitas características empreendedoras e, às vezes, se comporta como um; porém, você pode melhorar ainda mais se equilibrar os pontos ainda fracos com os pontos fortes.

- Perfil 3: 60 a 89 pontos: você ainda não é muito empreendedor e, provavelmente, se comporta, na maior parte do tempo, como um administrador e não um "fazedor". Para se diferenciar e começar a praticar atitudes empreendedoras, procure analisar seus principais pontos fracos e definir estratégias pessoais para eliminá-los.

- Perfil 4: Menos de 59 pontos: você não é empreendedor e, se continuar assim, dificilmente será um. Isso não significa que você não tenha qualidades, apenas

que prefere seguir a ser seguido. Se você pretende ter um negócio próprio, reavalie sua carreira e seus objetivos pessoais.

Com base nos resultados encontrados e mostrados nos gráficos, pode-se concluir que a grande maioria dos colaboradores da empresa de assessoria contábil do presente estudo possui um perfil empreendedor, pois numa amostra de 18 pessoas, 14 pessoas obtiverem uma pontuação entre 120 e 150 pontos na pesquisa de auto avaliação. As outras 4 pessoas restantes enquadram-se no segundo perfil, sendo necessário um maior aperfeiçoamento de alguns pontos fracos. Não foram identificados colaboradores que se enquadrassem nos perfis 4 e 5 . 
Gráfico 3 - Análise do Desempenho

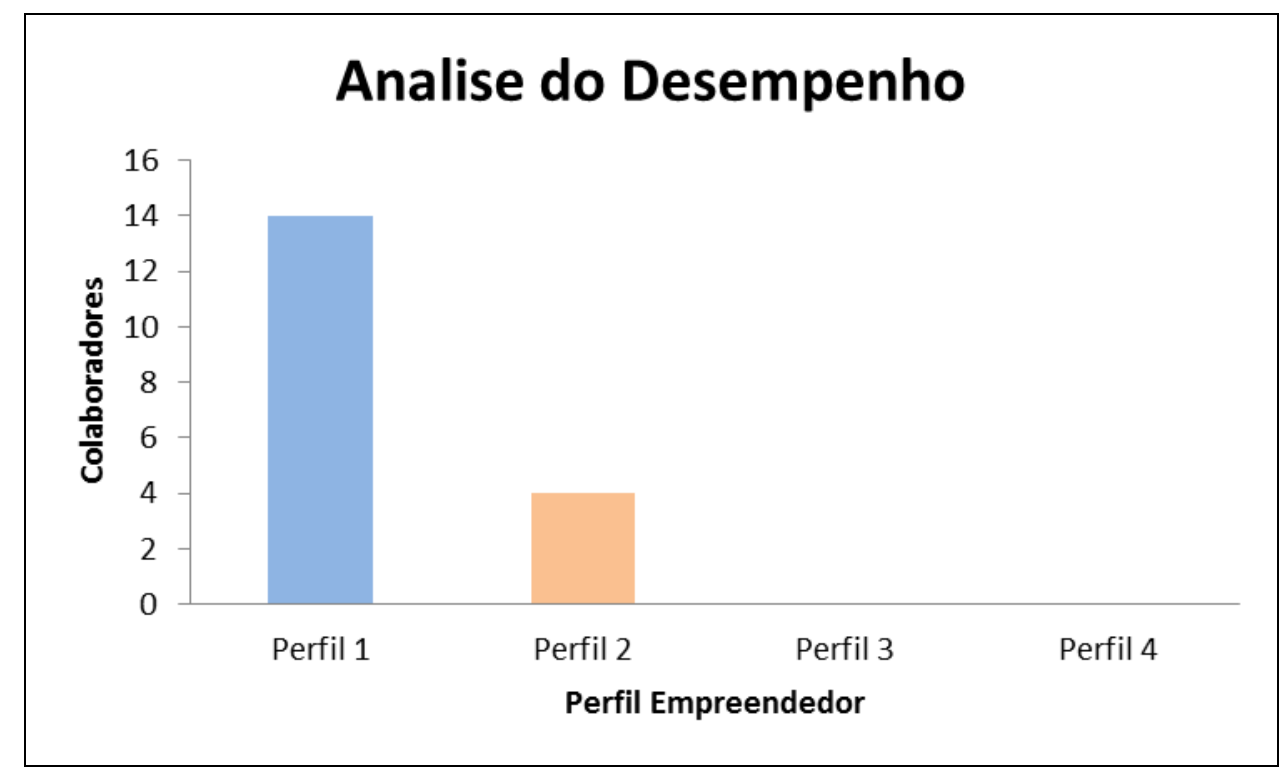

Fonte: A Autora (2017)

A partir dessa análise, pode-se verificar que a grande maioria possui um perfil empreendedor, no qual prevalecem às características que estão descritas através dos pontos principais de comprometimento e determinação; obsessão pelas oportunidades; tolerância ao risco, ambiguidade e incertezas; criatividade, autoconfiança e habilidade de adaptação; motivação e superação e liderança, de acordo com Dornelas, (2014).

Esses principais grupos das principais características estão compostos por diversas sub características, como consta a seguir:

1. Comprometimento e determinação

- É proativo na tomada de decisão

- É tenaz e obstinado

- Tem disciplina e dedicação

- É persistente ao resolver problemas

- É disposto ao sacrifício para atingir metas

- É capaz de imersão total nas atividades que desenvolve

2. Obsessão pelas oportunidades

- Procura ter conhecimento profundo das necessidades dos clientes 
- É dirigido pelo mercado (Market driven)

- É obcecado por criar valor e satisfazer aos clientes

3. Tolerância ao risco, ambiguidade e incertezas

- Corre riscos calculados (analisa tudo antes de agir)

- Procura minimizar os riscos

- Tolera as incertezas e falta de estrutura

- Tolera o estresse e conflitos

- É hábil em resolver problemas e integrar soluções

4. Criatividade, autoconfiança e habilidade de adaptação

- Não é convencional, tem cabeça aberta, pensa

- Não se conforma com o status quo

- É hábil em se adaptar a novas situações

- Não tem medo de falhar

- É hábil em definir conceitos e detalhar ideias

5. Motivação e superação

- É orientado para metas e resultados

- É dirigido pela necessidade de crescer atingir melhores resultados

- Não se preocupa com status e poder

- Tem autoconfiança

- É ciente de suas fraquezas e forças

- Tem senso de humor e procura estar animado

6. Liderança

- Tem iniciativa

- Tem poder de autocontrole

- Transmite integridade e confiabilidade

- É paciente e sabe ouvir

- Sabe construir times e trabalhar em equipe

Para melhor visualização, o gráfico 4 desmembra as porcentagens através da média de pontuação obtida para todos os principais itens que compõem as características empreendedoras: 


\section{Gráfico 4 - Porcentagem Média por Grupo das Principais Características Empreendedoras}

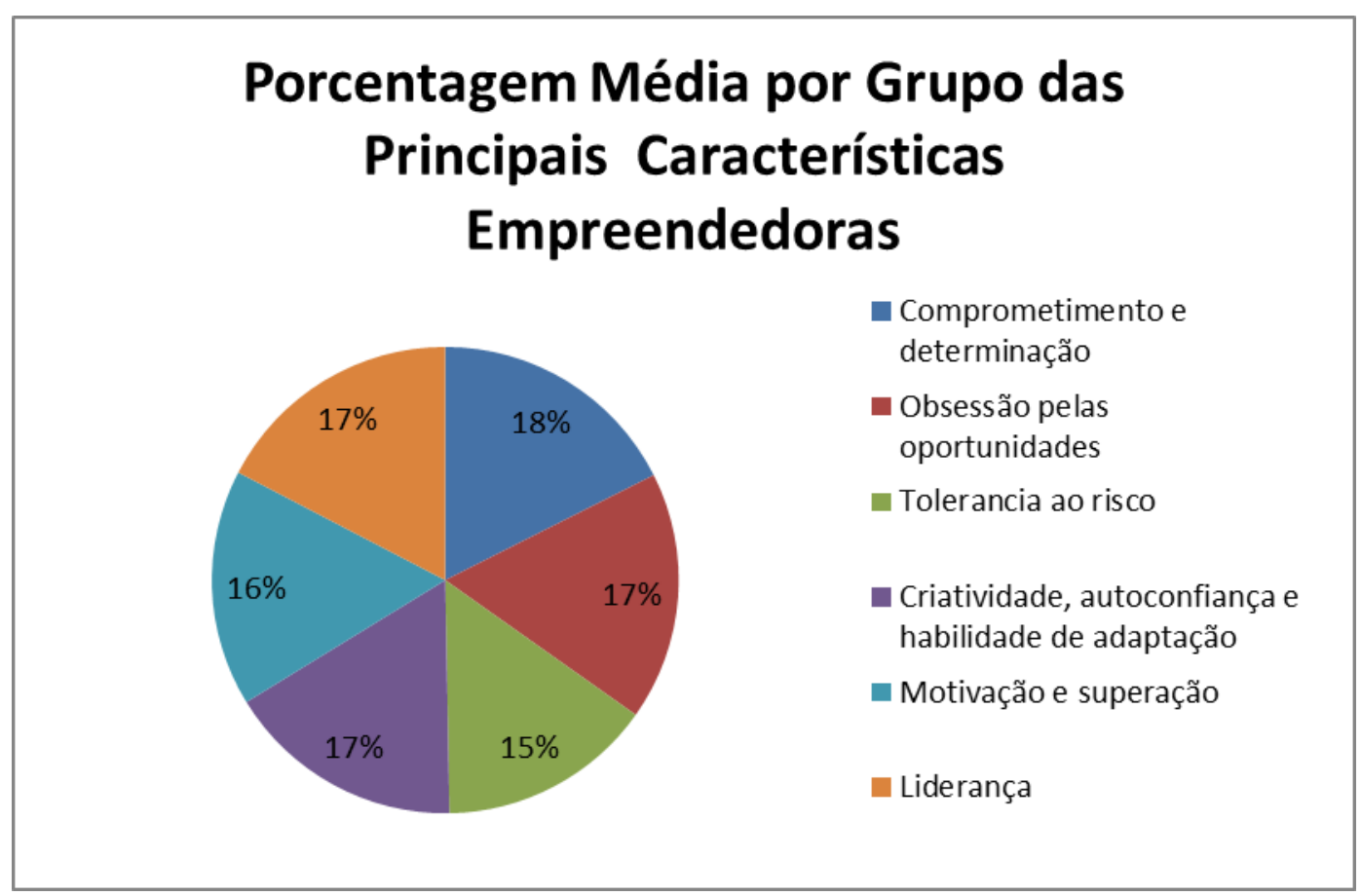

Fonte: A autora (2017).

Conforme pode-se observar, a característica que mais prevalece no perfil dos colaboradores é a de comprometimento e determinação, com 18\% da pontuação. De acordo com Dornelas (2007), pessoas que possuem esse perfil colocam em prática suas ações no dia a dia com total comprometimento. Enfrentam a barreira das diversidades e focam no objetivo final de "fazer acontecer". Além disso, eles procuram sempre estar antenados com tudo que acontece ao seu redor, sendo inconformados com a rotina e mantendo-se sempre dinâmicos. Profissionais com esse perfil também procuram dedicar-se ao máximo as suas atividades diárias referentes ao negócio. Muitos abrem mão da vida pessoal e as vezes acabam até mesmo comprometendo a própria saúde. São trabalhadores exemplares e conseguem contornar as situações adversas decorrentes do dia a dia.

Em segundo lugar, prevaleceram três características com $17 \%$ da pontuação cada uma, liderança, obsessão pelas oportunidades e; criatividade, autoconfiança e habilidade de adaptação.

Segundo Dornelas (2007), os empreendedores que possuem o perfil de líderes e formadores de equipes têm um senso de liderança diferenciado dos demais perfis dos 
profissionais presentes no mercado de trabalho. São bem aceitos e respeitados nas organizações devido a sua forma diferenciada de agir, valorizando e reconhecendo profissionalmente seus funcionários e os recompensando pelo seu trabalho formando, consequentemente, um time, uma equipe que luta em prol de objetivos em comum com o objetivo organizacional.

Já os empreendedores que possuem obsessão pelas oportunidades sabem explorá-las ao máximo. Para Schumpeter (1949), o empreendedor é aquele que quebra a ordem corrente e inova, criando mercado com uma oportunidade identificada. Para Kirzner (1973), o empreendedor é aquele que cria um equilíbrio, encontrando uma posição clara e positiva em um ambiente de caos e turbulência.

Os que se enquadram nas características do grupo de criatividade, autoconfiança e habilidade de adaptação querem estar à frente das mudanças e ser donos do próprio destino. Querem ser independentes, em vez de empregados; querem criar algo novo e determinar os próprios passos, abrir os próprios caminhos, ser o próprio patrão e gerar empregos. (Dornelas, 2007).

Representando $16 \%$ da pontuação, ficou a característica motivação e superação. Os empreendedores que possuem esse perfil, segundo Dornelas (2007), implementam suas ações com total comprometimento. Atropelam as adversidades, ultrapassando os obstáculos com muita vontade de "fazer acontecer". Mantêm-se sempre dinâmicos e cultivam certo inconformismo diante da rotina.

Por último, com 15\%, ficou o grupo de características de tolerância ao risco. Ainda segundo Dornelas (2007), o verdadeiro empreendedor é aquele que assume riscos calculados e sabe gerenciar o risco, avaliando as reais chances de sucesso. Assumir riscos tem relação com desafios. Para o empreendedor, quanto maior 0 desafio, mais estimulante será a jornada empreendedora.

A partir de análises individuais, através de uma escala de pontuação das características atribuídas por cada colaborador, foram extraídos os principais pontos fortes e os principais pontos fracos presentes no perfil de cada um, conforme consta no quadro dois abaixo. 


\section{Quadro 2 - Principais pontos fortes e pontos fracos dos colaboradores que responderam o questionário (Anexo 1).}

\begin{tabular}{|c|c|}
\hline Principais pontos fortes & Principais pontos fracos \\
\hline É tenaz e obstinado. & $\begin{array}{l}\text { Tolera as incertezas e falta de } \\
\text { estrutura. }\end{array}$ \\
\hline Tem disciplina e dedicação. & Tolera o estresse e conflitos. \\
\hline É persistente ao resolver problemas. & Não se preocupa com status e poder. \\
\hline $\begin{array}{l}\text { É disposto ao sacrifício para atingir } \\
\text { metas. }\end{array}$ & Não tem medo de falhar. \\
\hline $\begin{array}{l}\dot{E} \text { capaz de imersão total nas } \\
\text { atividades que desenvolve. }\end{array}$ & $\begin{array}{l}\dot{E} \text { dirigido pelo mercado (market } \\
\text { driven). }\end{array}$ \\
\hline $\begin{array}{l}\text { Procura ter conhecimento profundo } \\
\text { das necessidades dos clientes. }\end{array}$ & $\begin{array}{l}\text { Corre riscos calculados (analisa tudo } \\
\text { antes de agir). }\end{array}$ \\
\hline $\begin{array}{l}\text { Não é convencional, tem cabeça } \\
\text { aberta, pensa. }\end{array}$ & Não se conforma com o status quo. \\
\hline $\begin{array}{l}\dot{E} \text { hábil em se adaptar a novas } \\
\text { situações. }\end{array}$ & $\begin{array}{l}\text { É obcecado por criar valor e satisfazer } \\
\text { aos clientes. }\end{array}$ \\
\hline $\begin{array}{l}\text { É dirigido pela necessidade de crescer } \\
\text { e atingir melhores resultados. }\end{array}$ & É ciente de suas fraquezas e forças. \\
\hline $\begin{array}{l}\text { Tem senso de humor e procura estar } \\
\text { animado. }\end{array}$ & É orientado pelas metas e resultados. \\
\hline Tem iniciativa. & $\begin{array}{l}\text { É hábil em definir conceitos e detalhar } \\
\text { ideias. }\end{array}$ \\
\hline Tem poder de autocontrole. & É proativo na tomada de decisão. \\
\hline Transmite integridade e confiabilidade. & $\begin{array}{l}\dot{E} \text { hábil em resolver problemas e } \\
\text { integrar soluções. }\end{array}$ \\
\hline É paciente e sabe ouvir. & Procura minimizar os riscos. \\
\hline $\begin{array}{l}\text { Sabe construir times e trabalhar em } \\
\text { equipe. }\end{array}$ & Tem autoconfiança. \\
\hline
\end{tabular}

Fonte: A autora (2017). 
Os colaboradores 1 e 13 que responderam a pesquisa representam as empreendedoras e atuais sócias da empresa. Comparando-se o perfil das duas, podese observar que, por coincidência, as duas obtiveram a mesma pontuação total na pesquisa, totalizando 129 pontos e enquadrando-se no primeiro perfil empreendedor.

Porém, Comparando-se o perfil das mesmas com o perfil dos colaboradores no geral, podemos observar que, apesar de estarem enquadradas no primeiro perfil empreendedor igual a grande maioria dos colaboradores, elas não possuíram a maior pontuação; 6 colaboradores - Colaborador 4, Colaborador 5, Colaborador 6, Colaborador 9, Colaborador 14, Colaborador 18 - tiveram notas maiores do que elas, porém, a grande diferença é que não empreenderam ainda. Pode-se visualizar melhor o atual cenário descrito acima através do gráfico 5 .

\section{Gráfico 5 - Comparação do perfil das atuais empreendedoras com os demais colaboradores da empresa estudada}

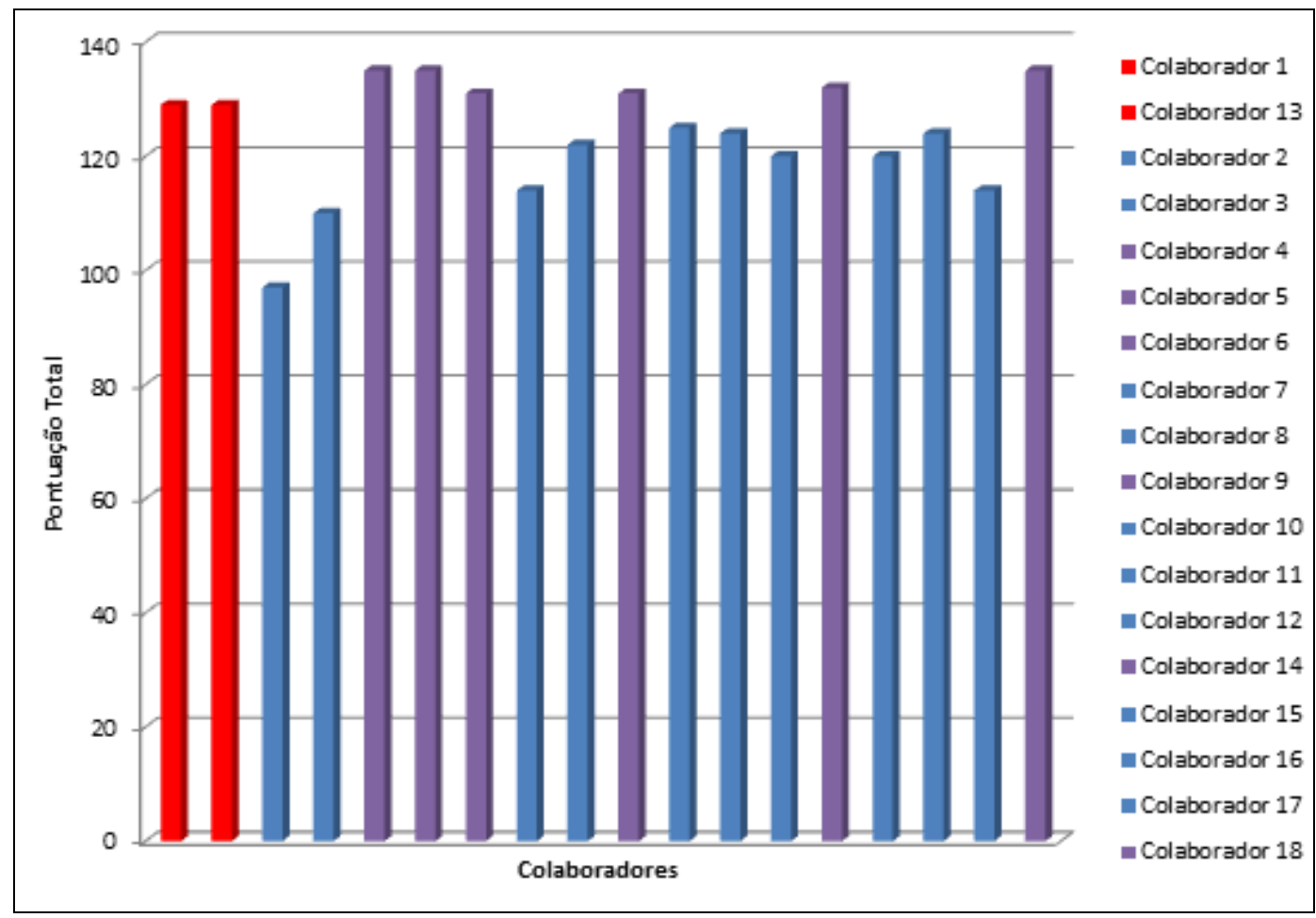

Fonte: A autora (2017). 


\section{Conclusão}

Este trabalho teve como propósito avaliar o atual perfil empreendedor dos trabalhadores perante o mercado de trabalho. Com isso, o objetivo principal era identificar o potencial do perfil empreendedor no desempenho dos colaboradores de uma empresa de assessoria de serviços contábeis na qual foi utilizada como exemplo para o presente estudo. Para tal identificação, foi aplicado um questionário (Anexo 1) elaborado por Dornelas (2007), de auto avaliação de diversas características pessoais, para que ao final, a partir de uma pontuação, fosse identificado o perfil desejado. O questionário foi aplicado para uma amostra de 18 pessoas, totalizando o número de colaboradores da empresa e os resultados foram analisados de forma quantitativa.

Com a presente pesquisa, pode-se observar que a grande maioria dos respondentes ficou classificada no primeiro perfil, que corresponde a um perfil de empreendedor, segundo a classificação feita pelo autor Dornelas (2007). Porém, apesar da grande maioria possuir esse perfil, ainda não empreendeu. Um fator estudado que pode impedir tal fato é a atual crise que o Brasil está vivenciando nos últimos anos, gerando grande instabilidade emocional e financeira, insegurança e resistência a mudanças, ou seja, os trabalhadores ficam mais inseguros para arriscar, principalmente quando se trata de uma ideia inovadora.

Outro fator que também se torna um impecílio para as pessoas empreender é falta de conhecimento no assunto, ou seja, a falta da educação empreendedora. Conforme foi citado no referencial teórico, no item 2.4, ainda existe uma falta de cultura e avaliação de impacto das iniciativas de educação empreendedora. Com isso, as pessoas se sentem inseguras de "dar o primeiro passo" por não conhecerem o processo ou até mesmo por não saberem identificar uma oportunidade.

Para um maior aprofundamento no assunto, o perfil dos colaboradores foi comparado com o perfil das empreendedoras, atuais sócias, da empresa. As responsáveis pela auto avaliação representada pelo colaborador 1 e colaborador 13 foram elas. Para que seja feito um maior aprofundamento no trabalho, podemos comparar o perfil empreendedor das mesmas com o perfil dos colaboradores restantes. Por coincidência, as sócias tiveram a mesma pontuação final, totalizando 129 pontos e enquadrando-se no perfil 1, no qual corresponde a um perfil de atual 
empreendedor. Porém, uma curiosidade que foi observada é que elas não possuíram as maiores pontuações; 6 colaboradores obtiveram notas maiores do que elas. Mas devido ao motivo descrito no parágrafo acima, não empreenderam.

A partir do desenvolvimento e construção do referencial teórico com o "cruzamento" do resultado obtido na pesquisa, foi possível concluir o objetivo final do presente trabalho. Foram confirmados alguns pontos importantes de como a instabilidade e o atual número de desempregados é um dos problemas mais sério e mais critico atualmente, chegando ao ponto de inibir a população de arriscar. Além disso, conforme descrito no capítulo da introdução, o Brasil é um país bastante desafiador para startups e empreendedores.

Quanto aos benefícios individuais que o questionário proporcionou para os colaboradores é o poder de uma auto avaliação do seu perfil, no qual muitos deles não tinham conhecimento, alguns pelo fato de não conhecerem a fundo os perfis empreendedores e outros por não terem tempo e oportunidade de se auto avaliarem, trazendo um resultado bastante curioso e representativo para futuras decisões.

Por fim, respondendo a pergunta problema formulada no inicio deste trabalho, pode-se inferir que no geral, a grande maioria dos trabalhadores possui um perfil empreendedor. Porém, isso não faz com que os mesmos já sejam empreendedores ou possuem planos de empreender. Para que ocorra uma melhoria no número de abertura de empreendimentos, conforme relatado pelo SEBRAE (2008), recomendase que haja um maior investimento, maior atenção e inovação nos processos de educação, com a inclusão de disciplinas que sejam voltadas para o tema empreendedorismo na grade curricular das escolas e das universidades. $O$ intuito dessa ação seria aprofundar e estimular o desenvolvimento de habilidades, valores e atitudes empreendedoras.

Além disso, esse estudo também teve como objetivo estimular os profissionais que já abriram o seu próprio negócio ou aqueles que ainda não abriram através do conhecimento do processo de abertura e das principais características de empreendedores de sucesso. Através do estudo realizado no referencial teórico, é possível buscar um conhecimento contínuo e moderado da atual situação do país, permitindo uma maior previsibilidade dos negócios.

Desta forma, conclui-se que o este estudo cumpriu seus objetivos intermediários e, consequentemente, alcançou o seu objetivo final.

Ouvimos diariamente que o Brasil é o país do futuro porém, infelizmente, esse futuro ainda está bem distante. A velocidade com que o país está crescendo não é compatível com nossa expectativa. Precisamos ampliar e despertar a atitude empreendedora para que ocorra uma aceleração no desenvolvimento econômico e 
desenvolvimento e crescimento profissional de cada ser humano. Se aumentarmos o capital social brasileiro, a postura de transparência e lealdade irá se tornar mais forte e, com isso, o país ganhará uma maior credibilidade em seu progresso.

\subsection{Sugestões e recomendações para futuras pesquisas}

Após a realização desse trabalho observa-se a necessidade de um maior autoconhecimento dos profissionais inseridos no mercado de trabalho e um maior aprofundamento no tema empreendedorismo por parte de cada um e por parte das escolas, universidades e até mesmo empresas.

Outro ponto bastante importante que pode-se levantar é das empresas observarem o quão importante e qual o impacto que a atitude empreendedora de cada funcionário pode ter diretamente no resultado final da organização. É muito importante que os funcionários entrem como um pensamento voltado para o empreendedorismo, para que ele tenha atitudes e pensamentos como se ele fosse o próprio sócio da empresa.

Além disso, deveria haver um maior incentivo por parte do atual governo para a abertura de novas startups, oferecendo um projeto para os empreendedores por um período de capacitação e a possibilidade do mesmo participar de licitações. O projeto existente hoje tem um número de inscrições bastante reduzido.

Por fim, seria interessante a realização de um trabalho que tivesse como objetivo verificar a satisfação dos funcionários no atual emprego, verificar se as atitudes e pensamentos dele estão de acordo com as metas e objetivos da empresa e, juntamente verificar a importância que os sócios e diretores dão para o perfil empreendedor de seus funcionários, ou seja, até que ponto esse perfil é valorizado dentro das organizações. 


\section{Referências Bibliográficas}

ALMEIDA, Joana Gomes; ALBUQUERQUE, Cristina Pinto. De Desempregados a Empreendedores. 1 ed. Viseu, Maio 2013.

ARANHA, JOSÉ ALBERTO. Interfaces: a chave para compreender as pessoas e suas relações em um ambiente de inovação. São Paulo: Saraiva, 2009.

CHIAVENATO, I. Administração nos novos tempos. Rio de Janeiro: Campus, 1999.

DOLABELA, Fernando. A Oficina do Empreendedor. São Paulo: Cultura Editores Associados, 1999.

DORNELAS, José Carlos Assis. Empreendedorismo: Transformando Ideias em Negócios. 5 ed. Rio de Janeiro: Empreende / LTC,2014.

DRUCKER, P.F. Inovação e inovação empreendedora: prática e princípios. São Paulo: Pioneira, 1987.

FARREL, L.C. Entreepreneurship. São Paulo: Atlas, 1993.

FILION, Louis Jacques. Empreendedorismo: empreendedores e proprietáriosgerentes de pequenos negócios. Revista de Administração, v. 34, n. 2, p. 05-28, abr./jun. 1999.

LENZI, Fernado César. A Nova Geração de Empreendedores. 1 ed. São Paulo: Atlas, 2009.

MAXIMIANO, A. C. A. Introdução a administração. São Paulo: Editora Atlas, 1992.

SALIM, Cesar Simões; SILVA, Nelson Caldas. Introdução ao Empreendedorismo: Despertando a Atitude Empreendedora. Rio de Janeiro: Elsevier, 2010.

SEBRAE. 10 Anos de Monitoramento da Sobrevivência e Mortalidade de Empresas/ SEBRAE-SP. São Paulo, 2008.

VERGARA, S.C. Projetos e Relatórios de Pesquisa em Administração. São Paulo: Atlas, 2000. 
Anexo 1 


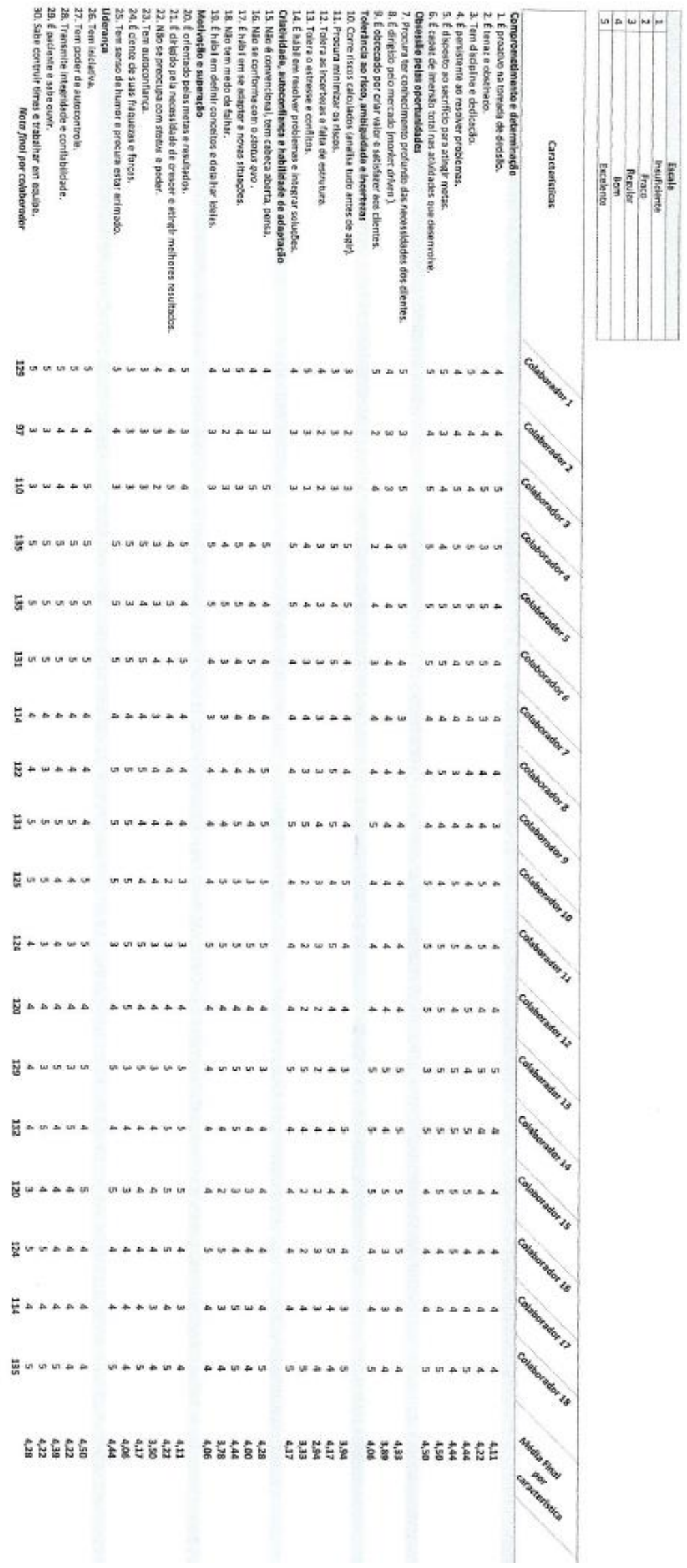

